\title{
UMBATRA
}

Indonesian Journal of Anthropology

Volume 5 (1) Juli 2020 || eISSN 2528-1569 | pISSN 2528-2115 || http://jurnal.unpad.ac.id/umbara

DOI : $10.24198 /$ umbara.v5i1.26843

\section{Orang Indo di Belanda: Identitas Campuran dan Pengelolaan Keragaman}

\author{
Selly Riawanti \\ Departemen Antropologi, FISIP, Universitas Padjadjaran \\ sriawanti@unpad.ac.id
}

\begin{abstract}
This paper discusses the relationship between ethnic identity and diversity management by the state, based on the case of the Indo people in the Netherlands. As descendants of mixed-marriage between persons from different ethnic groups who were also unequals in Netherland-Indies colonial society, their citizenship status changes from the colonial period to the decolonization period in the Indies, and eventually in the post-colonial Netherlands. The data is obtained from a qualitative research that consists of literature study and interviews with Indo people and an Indo organization in The Netherlands. Indo identity and culture contain 'foreignness' and 'nativeness', which could bring advantages or disadvantages, or even threaten their very existence, in different contexts of diversity management by the state. The study found different practices of indoness between three Indo generations in the Netherlands. Intergenerational Indo experiences has constructed a relatively open disposition among the younger generation on their identity and tolerance towards others in the increasingly multicultural Netherlands.
\end{abstract}

Keywords: mixed identity, citizenship, diversity management

\begin{abstract}
Abstrak
Tulisan ini membahas kaitan di antara identitas etnik warga dengan pengelolaan keragaman penduduk oleh negara, dalam kasus Orang Indo di Belanda. Sebagai keturunan dari perkawinan di antara pasangan berbeda etnik yang tidak setara kedudukannya dalam masyarakat kolonial Hindia Belanda, mereka mengalami perubahan-perubahan status kewargaan dalam tiga masa: masa kolonial Hindia Belanda, masa dekolonisasi, dan masa pasca kolonial di Belanda. Datanya didapat dari penelitian berpendekatan kualitatif yang bertumpu pada kajian pustaka dan wawancara dengan Orang Indo dan pengelola organisasi Indo di Belanda. Status kewargaan Orang Indo terkait dengan identitas dan kebudayaan mereka yang mengandung unsur 'keasingan' dan 'kepribumian'. Status itu bisa menguntungkan, bisa pula merugikan atau bahkan mengancam eksistensi mereka, dalam berbagai konteks pengelolaan kewargaan oleh negara. Ditemukan perbedaan praktik keindoan di antara tiga generasi Indo di Belanda. Pengalaman lintas generasi Indo, diserap oleh generasi muda yang lebih terbuka tentang identitasnya dan toleran terhadap liyan di masyarakat Belanda yang kini semakin multikultural.
\end{abstract}

Kata kunci: identitas campuran, kewargaan, pengelolaan keragaman 


\section{Pendahuluan}

Kajian ini membahas pengalaman kewargaan dari suatu golongan etnis campuran, yakni Orang Indo dalam kehidupan mereka sekarang di masyarakat Belanda pascakolonial. Istilah kewargaan (citizenship) merujuk ke status sebagai penduduk yang diakui sebagai bagian dari suatu masyarakat negara, dengan berbagai hak dan kewajibannya. Istilah pascakolonial digunakan dalam dua pengertian: secara harfiah ketika Belanda tidak lagi memiliki daerah jajahan atau koloni; secara lebih luas menyangkut pengaruh dari hubunganhubungan kolonial di antara penguasa dan yang dikuasai (Memmi, 1965). Istilah identitas campuran merujuk kepada identitas keturunan dari perkawinan silang di antara pasangan yang berbeda identitas etnisnya; dalam hal Orang Indo adalah perkawinan di antara orang Belanda dan orang pribumi nusantara.

Kajian tentang etnisitas dalam khazanah ilmu sosial di Indonesia lebih sering terfokus ke identitas etnik tunggal. Agak jarang perhatian ke gejala pertemuan dan pergaulan antaretnis yang menghasilkan percampuran identitas dan kebudayaan di antara orang-orang yang sebelumnya tergolong ke golongan etnis yang berbeda-beda, yang kerap disebut sebagai kreolisasi (Patterson, 1975; Stewart, 2007; Knörr, 2008; Oostindie, 2008). Mengikuti Patterson (1975), kreolisasi dapat terjadi melalui dua mekanisme, yakni 1) perkawinan antaretnik (kreolisasi sintetik atau biologis), dan 2) percampuran cara hidup berkat interaksi antaretnik yang intensif atau cukup lama di ruang tertentu (kreolisasi segmenter atau kreolisasi budaya). Proses kreolisasi yang dialami banyak individu dalam konteks yang sama, dapat membentuk suatu golongan etnis campuran, seperti Orang Betawi di Jakarta (Knörr, 2008). Orang Indo tergolong hasil kreolisasi seperti itu. Tetapi identitas campuran Orang Indo cukup kompleks, berhubung pasangan leluhurnya berasal dari dua golongan etnis yang berbeda secara horizontal sekaligus secara vertikal, di dalam struktur sosial masyarakat kolonial. Di Indonesia umumnya dipakai istilah 'Indo' untuk menamai golongan ini. Sedangkan di Belanda, selain Indo ada pula istilah Indisch, ${ }^{1}$ yang merujuk ke orang Belanda yang mengalami kreolisasi budaya akibat hidup lama di kepulauan Hindia.

\section{Kajian Pustaka}

Pustaka tentang Orang Indo yang tersedia dalambahasa Indonesia dewasa ini kebanyakan tentang kehidupan mereka di Indonesia atau Hindia dulu. Djoko Soekiman menulis dari sisi sejarah, Kebudayaan Indis dan Gaya Hidup Masyarakat Pendukungnya di Jawa, Abad XVIII-Medio Abad XX (2000). Karya lain tentang keindoan merupakan terjemahan dari Bahasa Belanda. Reggie Baay dalam De Njai: Het concubinaat in Nederlands-Indië (2008), membahas ihwal ibu pribumi Hindia dari kaum Indo. Yano Jonathans menulis Kaum Depok di Selatan Jakarta (2011), tentang sejarah suatu golongan penduduk yang menyebut dirinya Kaum Depok, dengan cara hidup kebelanda-belandaan berkat kreolisasi budaya yang berlangsung lama. Leluhur mereka adalah penduduk nusantara, terutama Bali dan Makassar, yang bekerja sebagai budakbudak VOC di Batavia. Beberapa budak itu diajak Cornelis Chastelein, seorang pejabat tinggi VOC dan pengurus Raad van Indie (Dewan Hindia), pergi ke arah selatan Batavia untuk membangun 'Masyarakat Kristen Baru (Protestan)', di tempat yang sekarang dikenal sebagai kawasan 'Depok Lama'. ${ }^{2}$ Karya suntingan Coté dan Westerbeek, Recalling the Indies: Colonial Cultures and Postcolonial Identities (terjemahan Indonesia 2014), lebih luas rentang masanya, meliputi pengalaman Orang Indo di masa Hindia Belanda sampai ke masa pascakolonial di Belanda dan Australia.

\footnotetext{
${ }^{1}$ Istilah indisch juga lazim merujuk ke hal-ihwal yang berkaitan atau berasal dari nusantara yang dulu disebut sebagai kepulauan Hindia (Indische archipel), misalnya Indische eten (makanan Hindia), Indische letteren (sastra Hindia), dan sebagainya.

2 Kadang-kadang mereka dirancukan dengan istilah 'Belanda Depok', yaitu keturunan dari perkawinan campur orang Belanda dan penduduk setempat. Orang Belanda Depok memang ada tetapi tidak banyak, dan nyaris semuanya telah pindah ke negeri Belanda (Jonathans 2011).
} 
Di Belanda, tulisan tentang Orang Indo berlimpah (De Vries, 2009; Oostindie, 2011; Bosma, 2008). ${ }^{3}$ Karya akademik biasanya sekitar sastra atau sejarah sosial politik dan ekonomi, dan hukum. Salah satu genre sastra Belanda adalah sastra Hindia (Indische belletrie). Buku Rob Nieuwenhuys, OostIndische Spiegel (1978), memaparkan sastra Hindia sejak masa VOC sampai pasca-Hindia Belanda, kebanyakan kenangan romantik tentang Hindia. Kajian sejarah kolonial selalu mengandung uraian tentang orang Indo, asalusul dan posisi mereka dalam masa VOC, Hindia Belanda, dekolonisasi dan pasca kolonial. Pada 1980-an bermunculan biografi karya generasi kedua Indo di Belanda. Isinya kenangan akan keindahan dari masa Hindia Belanda, dan kepahitan pada masa pendudukan Jepang di Hindia. Proklamasi Republik Indonesia dan proses dekolonisasi, menyingkirkan orang Belanda dan golongan lain yang terkait dengan mereka, dari segala ranah kehidupan di negara baru itu. Terjadilah penirbelandaan masyarakat (het verontnederlandsing van de samenleving, Voskuil, 1996:71), yang mendorong orang Indo pindah ke negeri Belanda.

Pustaka tentang pendatang Indo di Belanda menonjolkan inti kehidupan mereka untuk berasimilasi ke masyarakat dan kebudayaan Belanda, dengan menekan identitas dan ungkapan budaya Indo (Pollmann dan Harms, 1987; De Vries, 2009; Oostindie, 2011; Bosma, 2008; Staal, 2012; Iburg, 2013). Terdapat juga pustaka tentang resistensi untuk menjadi Orang Belanda, seperti tulisan-tulisan Tjalie Robinson. Sekarang di Internet berkembang laman-laman interaktif seperti indisch4ever (Indisch forever) yang dikelola generasi muda Indo, yang mengunggah dan mendiskusikan berbagai wacana keindoan dari masa lampau maupun masa kini Orang Indo di Belanda.

Tulisan ini bertolak dari pertanyaan pokok: bagaimana pengalaman kewargaan orang Indo dari masa kolonial Belanda di Hindia sampai ke Belanda pascakolonial? Bagaimana kaitan di antara pengalaman kewargaan tersebut dengan kebijakan-kebijakan negara dan praktik-praktik kewargaan Orang Indo sendiri?

Kewargaan sebagai suatu status sosial legal, sangat terkait dengan identitas dan pengakuan terhadap identitas tersebut dalam strukturstruktur yang mengatur hubungan di antara warga dan negara, dan di antara sesama warga negara. Namun kewargaan juga dapat diupayakan, baik melalui jalur hukum maupun cara-cara di luar hukum. Karangan ini akan memperlihatkan identitas keindoan dalam konteks sejarah masyarakat kolonial Hindia Belanda yang pluralistik, yang didahului oleh masa VOC dan diakhiri masa dekolonisasi. Pemahaman tentang identitas Indo di Belanda perlu memperhatikan kebijakan pemerintah Belanda dalam mengelola keragaman warga negaranya. Pemerintah Belanda pascakolonial sempat menerapkan kebijakan multikulturalisme, yang menekankan toleransi kepada perbedaan cara hidup penduduknya yang semakin beragam oleh pendatang dari berbagai negara. Akan diperlihatkan perwujudan etnisitas orang Indo dari beberapa generasi dalam konteks perkembanganperkembangan tersebut.

\section{Metode}

Data untuk karangan ini didapat dari penelitian secara kualitatif sekitar enam bulan, yang meliputi kajian pustaka dan tiga bulan penelitian lapangan di Belanda ${ }^{4}$. Pengumpulan data menggabungkan wawancara dan pengamatan. Satuan kajiannya adalah individu sebagai satuan yang paling mudah dijangkau, dan sebuah kolektiva, yaitu sebuah organisasi Indo di Den Haag. Kategorisasi Indo yang ditemukan di lapangan meliputi (a) kategorisasi orang Indo berdasarkan generasi: 'Indo Lama' (generasi pertama dan kedua) dan 'Indo Baru' (generasi ketiga dan setelahnya); dan (b) kategorisasi berdasarkan

\footnotetext{
${ }^{3}$ Tentu saja sebagian besar tulisan berbahasa Belanda. Baru di abad ini muncul upaya untuk meraih pembaca internasional dengan publikasi dalam bahasa Inggris (Bosma 2012:8)

${ }^{4}$ Penelitian ini didanai oleh program SAME (Scheme for Academic Mobility and Exchange) periode 2013 dari Direktorat Pendidikan Tinggi Kementerian Pendidikan dan Kebudayaan RI. Persiapan di Indonesia sejak bulan Juni 2013, penelitian di Belanda September-November 2013, penulisan laporan sampai Januari 2014.
} 
proses kreolisasi: Indo (kreolisasi biologis) dan Indisch (kreolisasi budaya).

Narasumber diperoleh secara bergulir. Para informan pangkal adalah pakar pustaka Hindia di KITLV di Leiden, dosen asal Indonesia di Universitas Leiden, staf asal Indonesia di Museum Etnografi Leiden, dan seorang pendukung pengembangan sosial ekonomi kampung di Bali, yang ditemukan dari lamannya di internet. Kontak dengan narasumber selanjutnya didahului melalui telepon dan email, untuk pertemuan sesuai dengan jadwal mereka. Narasumber berjumlah 18 orang, terdiri atas seorang informan pangkal, sepuluh orang 'Indo Lama', termasuk seorang perempuan yang status repatriannya didapat dari perkawinannya dengan seorang warga Belanda bukan kulit putih. Narasumber dari golongan 'Indo Baru' terdiri atas 6 orang generasi ketiga, dan satu orang generasi keempat. Dari segi kreolisasi, 15 narasumber adalah orang Indo dan 3 orang Indisch.

\section{Hasil dan Pembahasan}

\section{Siapakah Gerangan Orang Indo?}

Sejarah orang Indo di Belanda berakar pada masa kolonial Hindia Belanda yang cukup panjang. Berdasarkan konsep kreolisasi, terdapat dua golongan kreol dari pertemuan di antara Belanda dan Indonesia. Golongan pertama adalah Orang Indo yang merupakan hasil kreolisasi biologis (Patterson, 1975: kreolisasi sintetik) di antara orang Belanda atau Eropa lainnya (biasanya laki-laki) dengan orang pribumi nusantara (biasanya perempuan, dan kebanyakan dari kelas sosial rendah). Istilah lain adalah IndischNederlander atau Indo-Nederlander atau Indo-Europeaan jika pasangannya orang kulit putih bukan-Belanda. Indo-Eropa adakalanya disebut Eurasia, merujuk ke konteks kolonialisme Eropa di Asia. Istilah-istilah itu menggabungkan nama geografis (Hindia/ Indië; Nederland; Europe; Asia) dengan nama satuan sosial politik (bangsa, negara).

Golongan kedua adalah orang Indisch hasil kreolisasi budaya, yakni orang-orang Belanda yang lama tinggal di Hindia Belanda atau keturunan dari pasangan Belanda 'totok' yang lahir dan dibesarkan di Hindia Belanda, lalu mengadopsi cara hidup setempat (Patterson, 1975: kreolisasi segmenter, lokalisasi), terutama yang menambah kemudahan dan kenyamanan. Orang Indisch kelak dibedakan lagi, di antara mereka yang kembali ke Belanda seusai masa tugasnya di Hinda (trekkers), dan mereka yang memilih tetap tinggal di Hindia (blijvers). Dari kalangan blijvers, nantinya muncul gerakan yang mempromosikan kaum Indo di Hindia, bahkan sebagian dari mereka turut mempromosikan kemerdekaan Indonesia.

Dewasa ini di Belanda banyak sudah keturunan perkawinan antara orang Belanda dan orang Indonesia. Tetapi 'Indo' adalah istilah khusus bagi keturunan percampuran biologis dari masa kolonial Hindia Belanda, yang mulai tinggal di Belanda setelah dekolonisasi. Hingga kini telah ada empat generasi orang Indo di Belanda. Sejak generasi pertama, telah terjadi perkawinan lintas etnis lebih lebar lagi, di antara orang Indo dengan orang Belanda, atau orang-orang dari latar etnis dan bangsa yang berbeda lagi. Dari generasi termuda banyak yang tidak berbeda penampilannya dengan orang Belanda, namun ada pula yang fenotipnya menunjukkan ciri-ciri Asia.

\section{Identitas Indo dan Pengakuan Kewargaan oleh Negara}

Identitas orang Indo dan status kewargaannya tergantung kepada kebijakan pemerintah di tempat mereka hidup, dirunut dari asal muasal mereka di Hindia.

1. Versi pemerintah kolonial Hindia Belanda, 2. Versi pemerintah pendudukan Jepang di Hindia Belanda,

3. Versi pemerintah Republik Indonesia (masa revolusi, dekolonisasi),

4. Versi pemerintah Kerajaan Belanda pada awal migrasi Indo dari Hindia Belanda,

5. Versi pemerintah Kerajaan Belanda 2001 untuk ganti rugi bagi Orang Indo di Belanda,

6. Versi pemerintah Kerajaan Belanda dalam pengelolaan keragaman imigran di Belanda. 


\section{Orang Indo di Masa VOC sampai Hindia Belanda}

Identitas sebagai Orang Indo dan status kewargaannya dalam masyarakat kolonial, bergantung kepada pengakuan dari orangtua Belanda, biasanya adalah laki-laki (ayah). Jika diakui sebagai anak biologis ayahnya, ia akan mendapat kedudukan dan hak kewargaan yang sama dengan orang Belanda. Dalam hukum antargolongan di Hindia Belanda adalah gelijkgesteld (disetarakan).

Sebaliknya bila keturunan kawin campur itu tidak diakui sebagai anak biologis orang Belanda, maka kedudukan dan haknya disamakan dengan penduduk pribumi Hindia Belanda (inlanders). Dari pihak masyarakat asal ibunya, seringkali sang ibu mendapatkan cap buruk yang kemudian menurun kepada anaknya, sebagai keturunan yang telah 'tercemar' (Baay, 2008).

Persamaan kedudukan dengan orang Eropa (gelijkstelling) juga bisa didapatkan bila yang bersangkutan memiliki nama belakang Eropa dan penganut Kristiani. Contohnya adalah nama Eropa sebagai nama keluarga atau nama baptis pada orang-orang Maluku keturunan perkawinan campur pribumi dengan orang Portugis. Mereka boleh mengajukan gelijkstelling menjadi warga Belanda meskipun fenotipnya adalah pribumi (Pattipilohy, 2009). Status kewargaan juga diberikan berdasarkan perkawinan dengan warga negara Belanda, meskipun belum tentu ia merupakan orang Belanda 'biologis'. Misalnya, orang Suriname berkulit hitam yang tinggal di Hindia Belanda, berkewargaan Belanda karena Suriname merupakan jajahan Belanda (Tjen-A-Kwoei, 2013). Dengan kedudukan ini ia akan mendapat akses ke berbagai fasilitas sosial yang tersedia bagi orang Belanda/Eropa, seperti pendidikan, pelayanan kesehatan, dan sebagainya.

Namun pengakuan hukum tidaklah sama dengan pengakuan sosial. Dalam pergaulan hidup sehari-hari, perbedaan fenotip menjadi alasan pembedaan perlakuan. Sejak kanakkanak, Orang Indo dan pribumi kerap mengalami diskriminasi dari golongan kulit putih yang dominan, sementara itu kaum Indo menganggap kedudukan mereka lebih tinggi daripada pribumi pada umumnya (Pattipilohy, 2009; Tjen-A-Kwoei, 2013).

\section{Masa Pendudukan Jepang di Hindia Belanda (1942-1945)}

Pendudukan Jepang yangbermisi menunjukkan keunggulan Asia terhadap bangsa-bangsa Barat, segera menjungkirbalikkan struktur sosial di masyarakat Hindia yang semula dipuncaki orang Belanda. Pemerintah pendudukan Jepang tidak mengatur kewargaan negara penduduk Hindia-Belanda, misalnya mengubahnya menjadi bagian dari warga negara Jepang. Alih-alih, penduduk diklasifikasi berdasarkan 'kemurnian darah': Asia - bukan-Asia, yang diidentifikasi melalui ciri-ciri fenotip (warna rambut dan mata): Eropa/Belanda totok (volbloed) dan Asia/ Pribumi totok, dengan model kontinuum. Golongan yang 'paling asing', yaitu orang Eropa/Belanda, dikurung di dalam komplekskompleks tahanan (binnenkamp), diiringi kerja paksa di dalam atau di luar kompleks tahanan. Golongan pribumi, yang 'paling Asia', bebas dari kurungan; demikian pula sebagian kaum Indo yang 'darah'nya dianggap lebih dekat ke Jepang atau Asia, ditempatkan di luar tahanan (buitenkamp) tetapi di bawah pengawasan ketat, atau sama sekali tidak ditahan atau diawasi. Meskipun sebagian kaum Indo selamat dari kampen, namun sirnalah segala privilege yang mereka dapat semasa pemerintahan Hindia Belanda. Banyak orang Indo yang meluncur kedudukan sosial ekonominya ke anak tangga terendah.

\section{Masa Revolusi Kemerdekaan RI (Bersiap)}

Di ujung Perang Dunia II, rangkaian peristiwa politik yang kompleks memperburuk situasi orang Indo di Hindia. Jepang menyerah kepada pasukan Sekutu. Indonesiamemproklamasikan kemerdekaan pada 17 Agustus 1945, tetapi tidak diakui oleh pemerintah Kerajaan Belanda yang selepas pendudukan Jerman di Belanda dan pendudukan Jepang di Hindia, bermaksud menata kembali daerah koloninya. Tak lama setelah proklamasi, meletuplah permusuhan rakyat Indonesia kepada Belanda. Orang Indo yang memiliki darah Belanda, demikian pula 
mereka yang disetarakan (gelijkgestelden) diperlakukan sebagai musuh juga. Orang Indo juga banyak yang menjadi sasaran amarah penduduk Indonesia, terutama para pemuda. Orang Indo generasi pertama mengenang pengalaman-pengalaman terburuk seperti pembunuhan anggota keluarga, perkosaan, perampokan, dan sebagainya (lihat juga a.1. kajian Van Delden, 1989; Voskuil 1996; Staal, 2012; Frederick, 2010).

Belanda mengirimkan pasukan militer ke Hindia, Politionele Actie (oleh pihak Indonesia disebut sebagai Agresi Militer), pada tahun 1947 dan 1948, untuk menumpas gerakan-gerakan kemerdekaan Indonesia yang mengandung banyak kekerasan. Melalui kegagalan proses-proses diplomatik serta kekerasan oleh kedua pihak dan korban yang mencapai puluhan ribu jiwa, Belanda akhirnya mengakui kedaulatan Republik Indonesia. Orang Belanda harus melepaskan segala kekuasaan mereka atas orang dan sumbersumber daya Indonesia. Jabatan dan lembaga resmi atau perusahaan yang penting, diambil alih oleh Indonesia, 'dinasionalisasi'.

Sejak tahun 1946 pemerintah Kerajaan Belanda memulai program pemindahan warga negara Belanda ke negeri Belanda, yang disebut repatriëring (repatriasi, kembali ke tanah air). Ditawarkan dua pilihan: (1) 'pulang' ke Belanda, (2) memilih kewargaan Indonesia dan tetap tinggal di Indonesia. Opsi pertama sebetulnya hanya tepat bagi sebagian kecil warga Belanda di Hindia, kaum Indisch, khususnya ambtenaar (pejabat pemerintah) dan pengusaha Belanda yang secara harfiah mudik. Sedangkan sebagian terbesar, termasuk orang Indo yang lahir dan besar di Hindia, tidak pernah menginjak tanah Belanda. Opsi yang kedua lebih ditujukan kepada orang-orang Indo, dan memang termasuk diperjuangkan oleh partai politik Indo di Indonesia, seperti IEV (Indisch-Europeesche Vereniging, Persatuan Indo-Eropa). Tetapi sebagian orang Indo menjadi gusar, seperti kata informan ini:

"Gara-gara berdiri di pihak Belanda, kami jadi kehilangan segalanya. Waktu banyak orang Indo mau pergi (ke Belanda), pemerintah Belanda malahan berkata "Tempat kalian adalah di sana (Indonesia).“ Itu paling menyakitkan hati orang Indo, pemerintah yang kita bela begitu rupa ..."

Pemerintah Kerajaan Belanda menyediakan uang muka (rijksvoorschot) untuk biaya perjalanan dengan kapal laut ke Belanda. Akan tetapi persyaratannya cukup berat, sehingga sedikit saja orang Indo yang mendapatkannya. Itu pun kelak harus mereka bayar kembali. Seorang informan baru menyelesaikan angsurannya pada tahun 2000-an. Sebagian besar harus membiayai sendiri perjalanan mereka ke 'tanah air'.

\section{'Repatriasi' ke Belanda}

Orang Belanda dan orang Indo menjalani repatriasi ke Belanda antara 1946-1964, sejak masa revolusi sampai ke masa perebutan Irian Barat (Papua kini) oleh Indonesia pada tahun 1963. Orang Indo yang lahir dan dibesarkan di Hindia Belanda, hanya mengetahui negeri itu dari cerita atau dari pelajaran di sekolah. Maka banyak juga yang enggan meninggalkan Hindia, kampung halaman mereka (Boon dan Geleuken, 1993). Sebagian orang Indo bertahan di Indonesia, hidup bersama 'pribumi' yang mereka akrabi. Pemerintah Indonesia mengharuskan mereka menjadi warga negara Indonesia. Namun karena telanjur dipandang sebagai bagian dari musuh, mereka kerap menghadapi ancaman dari 'pemuda'. Tidak melihat masa depan bagi diri dan keturunannya, akhirnya mereka memutuskan untuk pergi juga, antara tahun 1950-1964. Mereka disebut kaum 'menyesal kemudian' (spijtoptant, a.l. Groenewald 2009). Spijtoptanten dipandang lebih rendah oleh Indo yang telah lebih dahulu memilih ke Belanda.

\section{Orang Indo di Belanda: Beban di Negeri Pasca Perang}

Pada tahun 1946, sekitar 300.000 Orang Indo dan warga negara Belanda lain dari Hindia Belanda mulai tiba di negeri yang baru berusaha bangkit dari kehancuran Perang Dunia II. Di Belanda juga banyak korban perang tersebut, di antaranya orang Belanda 
keturunan Yahudi dengan drama penderitaan yang dahsyat sebagai korban Nazi di bawah Hitler. Ratusan ribu calon penduduk yang pendidikannya kurang memadai sehingga mempergemuk angka pencari kerja bermutu rendah, dan dikhawatirkan menghambat rekonstruksi Belanda pasca perang. Rakyat Belanda yang baru lolos dari krisis pangan musim dingin 1944, tidak tergugah oleh kisah penderitaan pendatang dari Hindia, daerah yang, sependek pengetahuan mereka, subur dan penduduknya makmur.

Meskipun Ratu Juliana menyambut kedatangan mereka dengan pidato yang ramah, tetapi pemerintah Kerajaan Belanda separuh hati menerima mereka. Orang Indo, juga atas inisiatif IEV, semula diminta untuk bermigrasi ke Irian Barat, sekitar 4.000 orang. Kebijakan ini gagal ketika Indonesia menuntut Irian Barat sebagai bagian dari wilayah Republik Indonesia. Perdana Menteri Drees sempat pula menganjurkan orang Indo atau Indisch lainnya memilih negeri lain untuk migrasi lebih lanjut, a.1. ke Amerika Serikat (California), Brasilia, Australia, dan Selandia Baru atau Tasmania. Sekurangnya 60.000 orang Indo bermigrasi lagi meninggalkan Belanda pada tahun 1950an menuju daerah-daerah tersebut. Keturunan mereka bisa dijumpai di sana hingga kini (lihat a.1. Coté dan Westerbeek 2014, yang memuat satu bab wawancara dengan keturunan Indo di Australia)

\section{De Indische Kwestie: Ketidakadilan bagi Orang Indo di Belanda}

Orang Indo yang tetap tinggal di Belanda merasa perlakuan pemerintah kurang adil. Pemerintah tidak mengganti gaji pegawai negeri dan militer yang tidak diterima selama 41 bulan dalam tawanan Jepang, apalagi kerugian-kerugian yang diderita akibat perang. Mereka membandingkannya dengan penggantian kerugian yang diberikan kepada warga negara Belanda yang menderita banyak kehilangan selama masa pendudukan Jerman di Belanda. Selain itu, fasilitas yang diberikan kepada para repatriat dari Hindia-Belanda, yakni pelayaran ke Belanda, pakaian terutama untuk musim dingin, makanan, dan perumahan di Belanda, semuanya harus dibayar kembali dengan mengangsur, dipotong dari gaji yang didapat setelah bekerja di Belanda. Banyak keluarga yang baru bisa melunasinya 30 tahun kemudian (Tjen-A-Kwoei, 2013). Mereka membandingkannya dengan perlakuan kepada para pendatang di kemudian hari, terutama para pencari suaka, yang mendapatkan fasilitas kehidupan secara cuma-cuma dari pemerintah Belanda.

Kaum Indo di Belanda membentuk perwakilan untuk mendorong pemerintah Belanda memberikan ganti rugi atau tunjangan bagi mereka, sebagai pelipur bagi "sambutan pemerintah di masa lalu yang dingin, birokratis dan formalistik". Pada tahun 2001, akhirnya pemerintah Belanda memenuhi permintaan itu melalui kebijakan Het Gebaar (harfiah: iktikad baik). Dibuatlah rekonstruksi demografis untuk menentukan siapa yang berhak atas tunjangan tersebut:

- Dari angkatan 1945 (generasi pertama), sebanyak 288.000 orang, yang meliputi 245.000 orang Indo yang mengalami pendudukan Jepang, 34.000 orang Indo yang bersekolah di Belanda semasa Perang Dunia II, 23.000 orang bukan-Belanda asal Hindia dan menjadi warga negara Belanda, dan 25.000 orang Maluku yang tinggal di Belanda.

- Pada tahun 2001 tunjangan diberikan kepada 582.000 orang (termasuk generasi kedua), yaitu untuk 458.000 orang Indo yang tinggal di Belanda dan 124.000 yang hidup di luar negeri Belanda.

\section{Keindoan Antargenerasi}

Hingga saat penelitian ini, keturunan Indo di Belanda telah mencapai generasi keempat, meskipun mereka masih sedikit dan masih kanak-kanak. Ciri-ciri kehidupan sosial ekonomi orang Indo di Belanda terkait dengan generasinya, yang menurut Iburg (2013) terkait jarak terhadap peristiwa atau sejarah Indo di Hindia Belanda.

Generasi pertama Indo yang terpaksa meninggalkan Hindia menuju ke Belanda, pada umumnya merasa mengalami pemiskinan (verpaupering) sejak dilucuti kekayaan materi mereka oleh tentara pendudukan Jepang di Hindia Belanda. Keadaan ini berlanjut pada masa revolusi, ketika orang Indo menjadi 
sasaran permusuhan orang Indonesia kepada Belanda. Tatkala akhirnya terpaksa pergi ke Belanda (Pollmann dan Harms, 1987; Boon dan Geleuken, 1993) mereka betul-betul tidak memiliki harta yang berharga. Bahkan pakaian pun mereka dapatkan dari panitia repatriasi dari Kerajaan Belanda, selain jatah makanan dan perumahan serta pelayanan kesehatan dan, nantinya di Belanda, pendidikan. Biaya perjalanan ke Belanda dengan kapal laut yang mencapai ribuan gulden per keluarga, harus dikembalikan kepada pemerintah Belanda dengan mengangsur.

Mereka harus berupaya keras beradaptasi dengan lingkungan dan masyarakat Belanda yang pada waktu itu juga baru bangkit dari kehancuran Perang Dunia II dan karena itu tidak menyukai pendatang dari Hindia. Rentetan pengalaman pahit itu menyebabkan generasi pertama orang Indo di Belanda cenderung menyimpan dalamdalam penderitaan mereka dan berorientasi ke masa depan, terutama untuk peningkatan mutu kehidupan anak-anak mereka. Mereka berupaya keras untuk mematuhi peraturan perundangan dan norma-norma sosial budaya Belanda. Mereka berbahasa Belanda dengan sangat baik, selalu berpakaian rapi, dan mendisiplinkan anak-anak mereka dengan memakai model anak Belanda yang dianggap sukses.

Generasi pertama Indo kerap merasa terbelah di antara dua dunia: dunia Hindia yang diakrabi dan nyaman, dan dunia nyata di Belanda yang mendiskriminasi mereka. Salah satu gurauan pahit mereka adalah bahwa Indo itu singkatan dari "in Nederland door omstandigheden" (di Belanda karena keadaan yang memaksa). Mereka berusaha keras berasimilasi, membelandakan diri, sebisanya menekan identitas keindoannya.

Namun, dari generasi pertama ada tokoh yang menolak pilihan antara asimilasi ke kebudayaan Belanda atau kembali ke kebudayaan Hindia (Indonesia). Sebetulnya ia kelahiran Belanda, tetapi sejak kecil mengikuti orangtuanya ke Hindia. Tokoh

${ }^{5}$ Pasar malam berkala digelar juga di kota-kota lain di Belanda, setidaknya ada 20, meskipun tidak sebesar Tong Tong Fair. Belakangan, kedutaan besar Indonesia juga membuat Pasar Malam Indonesia di Den Haag, yang sangat mirip dengan Tong Tong Fair (lihat studi Steijlen 2014) ini, Jan Boon yang terkenal dengan nama Tjalie Robinson, memelopori pelestarian dan pengembangan cara hidup Indo, yang merupakan campuran sana-sini, sekaligus terbuka kepada keragaman kebudayaan dunia. Perjuangannya dilakukan melalui tulisan-tulisan yang tajam cerdas kritis, dan mengorganisasi perkumpulan Orang Indo di Belanda, lengkap dengan sarana publikasi dan berbagai kegiatan yang merayakan keindoan, termasuk berupaya mengangkat bahasa Indo. Bahasa Indo yang dikenal dengan istilah Petjoh merupakan bahasa kolokial, dengan kosa kata Belanda tetapi berstruktur kalimat Indonesia atau Melayu Pasar, atau bahasa daerah tempat orang-orang Indo itu tinggal. Warna campur aduk itu menyebabkan bahasa Petjoh dipandang rendah.

Warisan Tjalie Robinson, kecualibahasa Petjoh yang tampaknya tinggal sisa-sisanya saja di Indonesia, masih bertahan dan berkembang hingga kini. Ia membentuk yayasan Orang Indo yang bernama Stichting Tong Tong. Yayasan ini menyelenggarakan festival tahunan Indo yang bernama Pasar Malam Besar, ${ }^{5}$ kemudian menjadi Pasar Malam Tong Tong (kentongan), dan sekarang menjadi Tong Tong Fair, di Den Haag; membuat berbagai publikasi seperti majalah populer Moesson dan studi-studi tentang Orang Indo, serta berbagai kegiatan lain. Pengelola yayasan dan kegiatan rutinnya adalah keluarga besar Tjalie Robinson. Sepeninggalnya, yayasan dikelola oleh menantu serta para cucunya.

Pada umumnya cara hidup Indo di rumah memiliki beberapa ciri khas yang menandai keindoan itu, terutama dalam hal kebersamaan, makanan khas Indo yang lebih berempah daripadamakanan Belanda, bermusik bersama, cara berpakaian yang santai di rumah. Bahasa Petjoh tidak lagi hidup di Belanda, kecuali penggunaan sedikit kosa kata Indonesia yang digabung dengan kosa kata Belanda seperti 'zich senang voelen' (merasa senang), 'een pientere vent' (anak pintar), dan sebangsanya. Dalam bidang musik, warisan generasi pertama Indo di Belanda adalah musik rock 
yang disebut Indo-Rock dengan kelompok band yang terkenal pada tahun 1960-1970an seperti The Blue Diamonds dan The Tieleman Brothers, atau kelompok pemusik jazz di Den Haag, dan untuk generasi pertama dan kedua, musik keroncong.

Beberapa orang Indo memprakarsai organisasi yang mengurus nasib Orang Indo, a.1. De Indische Kwestie, Het Indisch Platform, perwakilan resmi masyarakat Indo di Belanda, dan mitra pemerintah dan parlemen mengenai urusan kaum Indo; menjalankan politik kewargaan. Hingga kini berkembanglah berbagai yayasan yang menangani masalah sosial orang Indo, seperti panti-panti lansia dengan 'pendekatan Hindia'; kelompok studi sejarah Indo yang menyelenggarakan pertemuan dan diskusi rutin dengan tema keindoan atau tema-tema masa kini, termasuk mengikuti perkembangan berbagai hal di Indonesia.

Generasi kedua yang mendapatkan enkulturasi dan sosialisasi pro-asimilasi ke Belanda, dengan sendirinya menjadi 'lebih Belanda' daripada orangtua mereka. Meskipun demikian, cara hidup mereka dalam lingkungan keluarga luas masih seperti pada generasi pertama. Mereka pun menganggap kebersamaan, termasuk kebiasaan mengajak makan siapa saja yang kebetulan ada di sekitar, bermusik, sebagai hal yang penting dalam hidup.

Generasi kedua ini sekarang telah berusia 65 tahun lebih. Umumnya mereka sudah pensiun. Mereka membesarkan anak dengan cara Belanda pula, sehingga ketika anak sudah remaja lanjut atau dewasa muda, biasanya mencari tempat tinggal sendiri di luar rumah orangtua. Maka, orangtua memiliki waktu untuk menggali masa lalu mereka. Mereka mengingat kisah masa lalu orangtua, atau mungkin turut mengalami masa ketika orangtua tertindas di Hindia dan tersisih di Belanda; tetapi masih kecil untuk dapat memahaminya. Jadi ketika memiliki waktu, generasi ini menggali dan menelusuri riwayat kaum Indo di Hindia, dan mengungkapkannya dalam tulisan. Tahun 1980-an adalah masa produktif publikasi tulisan tentang keindoan, yang kebanyakan dihasilkan oleh generasi ini. Seorang pria generasi kedua yang mahir berpencak silat, beristerikan seorang perempuan dari Surakarta. Anak lakilakinya yang berusia 14 tahun akrab dengan mertuanya, dan mencicipi diasuh dalam kebudayaan Jawa: "Saya harap dia akan mewarisi peradaban rohani dan adat istiadat dari salah satu kebudayaan yang paling luhur di dunia”. Orang Indo generasi kedua banyak menjadi pengunjung setia pasar-pasar malam Indo yang tersebar di berbagai kota yang banyak orang Indonya. Bahkan tampak ada semacam subkultur Indo yang dipelihara oleh generasi ini (Seriese, 2005).

Generasi ketiga dan seterusnya, sama sekali tidak memiliki pengalaman langsung dengan Hindia Belanda. Pada generasi ini, pertalian dengan Indo dibentuk oleh enkulturasi dalam keluarga. Bila salah satu saja orangtuanya adalah Indo, apalagi bila keduanya, kemungkinan besar mereka mendapatkan pengalaman budaya Indo seperti dalam hal makan, kebersamaan, selera seni, dan lainlain. Adapun bahasa Indonesia tidak penting lagi, karena memang tidak memiliki kegunaan praktis sehari-hari. Bahasa kedua mereka adalah bahasa Inggris, atau bahasa Eropa lain seperti Spanyol dan Prancis. Seorang informan saya menyatakan, longgarnya ikatan dengan latar keindoan adalah 'dosa' generasi kedua yang tidak memperkenalkan mereka dengan kebudayaan Indo.

Mereka mengalami dan mewujudkan identitas Indo dengan cara berbeda dari kedua generasi sebelumnya. Pilihan identitas pun lebih banyak: sebagai warga negara Belanda, mahasiswa atau pekerja, penggemar film, penghuni kawasan permukiman kelas sosial tertentu, dan yang paling umum adalah kehidupan di dunia multimedia. Seorang peneliti menyebutkan bahwa keindoan tidak lagi penting bagi mereka, apalagi penampilan ragawi mereka sudah seperti orang Belanda pada umumnya. ${ }^{6}$

\footnotetext{
${ }^{6}$ Ibunya, generasi kedua, menikah dengan orang Belanda. Mungkin ini yang disebut Oostindie sebagai hypergamy, perkawinan silang dengan golongan yang lebih tinggi status sosialnya dalam struktur sosial yang ada, dalam hal ini dengan pribumi Belanda, Belanda totok. Namun istilah hypergamy bisa terdengar agak melecehkan, terutama
} 
Meskibegitu, seorangnarasumberdarigenerasi ketiga dengan antusias menyatakan betapa penting baginya mempelajari kebudayaan Indo, justru karena dari fenotipnya, sama sekali tidak tampak keindoannya. Rambutnya pirang, dengan wajah dan potongan tubuh "sangat Belanda". Setengah mengeluh, katanya:

"Orang tidak mau percaya bahwa saya ini Indo ... saya harus selalu menjelaskan silsilah keindoan saya, bahwa saya generasi ketiga Indo di sini."

Kerjanya di museum etnografi Leiden, membuatnya sering berurusan dengan artefak dan informasi tentang Indonesia, tugas yang sangat disukainya.

Namun identitas Indo tampaknya tidak begitu penting lagi bagi mereka. Menurut Iburg (2013), generasi ini dengan mudah dan praktis menjalin atau memutuskan hubungan dengan sesama Indo melalui media sosial. Kalau ada yang menekan 'like' pada laman pribadi mereka di Internet, biasanya sudah cukup alasan untuk dianggap menjadi sesama Indo. Tetapi di luar kesamaan latar belakang leluhur itu, mereka sangat beragam. Minat menelusuri latar keindoan atau 'mencari akar' (wortels, roots) mereka tampaknya sejajar dengan minat remaja atau orang muda dari semua golongan pendatang di Belanda. Meskipun mereka sudah menjadi warga negara Belanda, tetapi identitas yang khas tetap penting, jadi identitas sebagai keturunan Indo menjadi sesuatu yang menyenangkan. Sebagian lagi bersikap lebih santai, terutama jika sudah tidak memiliki kerabat di Indonesia. Generasi muda ini tidak merasa perlu mempelajari Bahasa Indonesia untuk mengenali asal usul leluhurnya. Mereka juga bersikap terbuka pada berbagai kemungkinan untuk masa depannya, apakah tetap menjadi warga negara Belanda, pindah ke negeri maju lainnya, pindah ke Indonesia, atau ke tempat lain lagi. Seorang informan dari generasi ini mengatakan bahwa ia adalah warga dunia, bisa menjadi orang apa saja. bagi generasi muda dengan kesadaran antirasialisme. Perkawinan, menurut mereka, harus karena saling menyukai. Konon banyak orang muda Belanda menyukai orang muda Indo yang dinilai rupawan.

${ }^{7}$ Konsep tempat berkumpul yang bukan rumah (tempat pertama) atau tempat kerja (tempat kedua), seperti rumah makan, balai pertemuan, taman, dan lain-lain (Oldenburg 1989).

Memelihara Keindoan. Keluarga Indo dari generasi pertama dan kedua mempraktikkan cara hidup Indo di rumah dan di beberapa tempat ketiga (third place) ${ }^{7}$, yakni tempat pertemuan umum seperti rumah makan, café, gedung pertemuan, atau di tempat terselenggaranya acara seperti pasar malam. Di kemudian hari, internet yang membuka ruang bagi media sosial juga dianggap sebagai semacam tempat ketiga. Di kalangan orang Indo di Belanda, internet dimanfaatkan untuk membuat laman, blog, dan sebagainya, yang aktif mengunggah data dan diskusi tentang keindoan. Di rumah, beberapa atribut identitas keindoan yang kerap menjadi bahan olok-olok di kalangan mereka sendiri atau dengan orang Belanda dan lainnya yang menjadi sahabat mereka adalah: botol cebok, guling, sambal dan makan enak, musik rock, dan banyak lagi. Konon keluarga Indo juga mengajarkan sikapsikap yang dianggap baik seperti menahan diri atau tidak menonjolkan diri (meskipun karena itu seringkali oleh orang Belanda mereka dianggap terlalu pasif atau tidak punya pendapat); tidak menolak tamu yang datang tanpa janji, mengajak tamu makan bersama. Namun praktik keindoan semacam ini tidak selalu bisa berlangsung pada semua keturunan Indo, terutama bila mereka telah membentuk keluarga dengan pasangan bukan-Indo.

Selain enkulturasi dan sosialisasi keindoan di lingkungan kerabat atau sesama Indo, terdapat pula acara peringatan yang lebih formal, yaitu Nationale Herdenking 15 augustus 1945. Sebenarnya ini bukan peringatan tentang orang Indo itu sendiri, melainkan peringatan akan kebebasan Belanda dari Perang Dunia II, yang di Hindia terkait dengan kebebasan dari pendudukan Jepang. Peringatan ini diprakarsai oleh Stichting Herdenking 15 augustus 1945 sejak 1970. Dewasa ini sebuah laman khusus untuk peringatan ini (15augustus1945.nl) aktif menghimbau orang Indo menghadiri upacaranya, mengajak cucu dan buyut mereka juga untuk turut mengheningkan cipta mengenang leluhur yang gugur di Hindia.

Acara lain yang sering diselenggarakan dalam Submitted: 02 February 2020

|| Reviewed: 22 February 2020

|| Accepted: 16 March 2020

25 
upaya memperingati keberadaan dan peranan kaum Indo di Hindia dan di Belanda adalah diskusi-diskusi, oleh berbagai yayasan Indo yang sekarang hidup di Belanda. Salah satu topik yang kerap muncul dalam diskusi seperti itu adalah kelalaian pemerintah Belanda mengurus orang Indo, dibandingkan dengan fasilitasi yang diberikan pemerintah kini terhadap para imigran dari kawasan lain di dunia.

Namun dari kalangan informan dari generasi ketiga yang saya temui, yang memang tidak banyak dan karenanya tidak representatif untuk generasi ketiga Indo di Belanda, tampaknya kurang aktif mengikuti upacara 15 Augtus 1945 atau acara-acara diskusi keindoan ${ }^{8}$.

\section{Orang Indo di Masyarakat Multikultural Belanda}

Belanda sesungguhnya bersifat multikultural sejak lama, meski dari luar, negeri kecil ini tampak relatif homogen. Sesungguhnya terdapat keragaman budaya geografis, misalnya di antara orang Utara dan orang Selatan, dalam dialek berbahasa, atau di antara orang kota dan orang desa. Salah satu penggolongan penting dalam masyarakat Belanda adalah ideologi. Dimulai dari agama, terdapat penggolongan dari Katolik ke Protestan dan beberapa reformasi lagi dari kalangan Protestan, yang diperkuat oleh berbagai pranata atau institusi sosial pelengkapnya, dari pendidikan agama sampai pendidikan sekuler, partai politik, dan media massa. Gejala ini disebut sebagai verzuiling, atau masyarakat berpilar, yakni suatu masyarakat yang ditopang oleh berapa pilar (zuil, zuilen) yang masing-masing kokoh berdiri sendiri, tetapi secara bersama menunjang dan dinaungi oleh suatu platform negara (Oostindie, 2008). Namun verzuiling ini lambat laun memudar seiring dengan perkembangan paham liberal di masyarakat Belanda sejak akhir 1960-an.

Sejak lama pula Belanda telah kedatangan migran yang berbeda-beda. Pada akhir 1960-an, jumlah pendatang baru di negeri ini sekitar 400.000 orang. Kebanyakan di antaranya adalah migran pascakolonial, dari daerah bekas jajahan Belanda: 300.000 dari Hindia-Belanda (repatriasi sejak tahun 1946), dan 30.000 dari Hindia Barat (Karibia, Suriname). Secara umum, para pendatang itu harus berasimilasi ke kebudayaan Belanda, seperti yang dialami generasi pertama Indo. Hingga kini terdapat pengakuan umum bahwa adaptasi migran dari kawasan kolonial, khususnya dari Hindia Belanda, ke masyarakat dan kebudayaan Belanda berlangsung dengan mulus (geruisloos). Penjelasannya adalah pada latar belakang kolonial yang mengorientasikan masyarakat jajahan ke kebudayaan penguasa, sehingga secara tidak langsung mempersiapkan mereka untuk berasimilasi di negeri 'induk'. Selain itu banyak migran pekerja juga dari negaranegara Eropa seperti Italia, Polandia, Belgia, Jerman, dan lain-lain.

Migran pasca perang dari Hindia, kecuali kelompok Cina-Hindia yang tidak begitu besar, dapat dibagi ke dalam tiga golongan: orang Belanda dari kelahiran (totok), orang Indo, dan sekelompok kecil orang Maluku. Tiap golongan ini memiliki sejarahnya sendiri-sendiri, di antara mereka merasa saling berbeda, demikian pula di Belanda. Apa yang agak mempersamakan mereka adalah suatu rasa ketidakpuasan yang mendalam akan kehilangan tanah kelahirannya dan akan sambutan yang dingin di negeri dingin Belanda. Hal ini menguatkan semacam rasa kebersamaan dalam tuntutan mereka kepada pemerintah Belanda, namun sangat lemah untuk mengurangi garis-garis perbedaan yang didapat sejak masa kolonial, meskipun kehadiran bersama mereka di acara seperti Pasar Malam Besar di Den Haag dapat menimbulkan kesan berbeda.

Berikutnya, sejak 1970-an di Belanda berdatangan pula para pekerja migran dari Maroko dan Turki yang umumnya beragama Islam. Mereka datang memenuhi kebutuhan pemerintah dan pengusaha Belanda akan pekerja kelas rendahan. Para pendatang ini kemudian disebut sebagai golongan minoritas. Berangsur-angsur masyarakat Belanda maupun pemerintahnya menjadi lebih liberal, menganut azas multikulturalisme,

\footnotetext{
${ }^{8}$ Hal ini masih memerlukan penelitian, karena di laman-laman keindoan cukup sering tampil wajah-wajah muda.
} 
yakni mengizinkan pekerja pendatang mempraktikkan kebudayaannya sendiri; meskipun di tempat-tempat umum mereka harus tunduk kepada norma dan hukum nasional yang berlaku, sebagaimana warga negara Belanda lainnya. Beberapa informan saya agak iri terhadap kebijakan pemerintah Belanda yang memberikan ruang ekspresi budaya sendiri bagi para pekerja migran itu. "Mengapa di paspor kita tak tercantum 'Indisch' atau 'Indo' di belakang kata Nederland? Atau membuat sekolah untuk anak-anak Indo supaya mereka belajar bahasa Indonesia?"

Secara umum, Belanda membagi penduduk berdasarkan asalnya, yaitu autochtonen ('pribumi') dan allochtonen (pendatang asing). Allochtonen dibagi lagi atas westerse allochtonen (pendatang dari negeri-negeri Barat, termasuk dari Hindia/Indonesia karena ada unsur Belandanya) dan niet-westerse allochtonen (pendatang dari daerah bukanBarat). Keasingan dihitung hingga dua generasi, seperti pada orang Indo: generasi pertama lahir di luar Belanda, generasi kedua keturunan dari orangtua yang lahir di luar Belanda. Oleh karena itu generasi ketiga Indo tidak lagi dihitung sebagai pendatang asing, mereka termasuk autochtonen. Kaum Indo menghilang dari kategori statistik golongan asing (allochtones) pada laporan CBS tahun 2014. Jumlah mereka sekarang mendekati setengah juta jiwa, seperti migran dari Karibia (Caraibische Nederlanders). Sejak 2016, Centraal Bureau voor de Statistiek mengganti istilah-istilah tersebut dengan bevolking naar migratieachtergrond (penduduk dengan latar belakang migrasi), meskipun tetap memakai kategori Barat dan bukan-Barat.

Pendatang, terutama migran pekerja, disebut sebagai kaum minoritas berdasarkan statistik dan status mereka dalam struktur sosial Belanda. Wacana tentang minoritas bergeser fokusnya ke pendatang yang beragama Islam (disebut Islamitische Nederlanders) yang jumlahnya sekarang mendekati angka sejuta jiwa. Migran Muslim semula dianggap akan sama dengan orang Belanda yang meninggalkan verzuilingnya, menjadi lebih liberal. Ternyata agama tetap penting bagi Muslimin, dan sikap multikulturalisme pemerintah maupun masyarakat Belanda memungkinkan mereka mempertahankan dan mengembangkan pranata-pranata keagamaan di Belanda. Berkembanglah lembaga-lembaga pendidikan khusus Islam, dan hari-hari besar Islam diterima sebagai alasan absensi di tempat kerja maupun di sekolah. Ada sebagian sangat kecil orang Indo atau berlatar Indonesia yang menjadi anggota dari perkumpulanperkumpulan Islam di Belanda; tetapi ini tidak seberapa bila dibandingkan dengan perkembangan orang Maroko dan Turki. Akhirnya gejala ini seperti mengembalikan Belanda ke model verzuiling.

Warga Belanda semakin kritis memandang gejala ini, terutama ketika terjadi peristiwa pembunuhan tokoh seniman dan tokoh politik aliran kanan oleh pendatang Islam. Bahkan salah satu tokoh politik sayap kanan yang terang-terangan menentang toleransi terhadap cara hidup imigran Islam adalah seorang Indo?. Akhirnya di antara 2010-2012, negeri ini meninggalkan kebijakan multikulturalisme, dan kembali menerapkan azas asimilasionisme untuk mengelola peningkatan keragaman penduduknya oleh kedatangan imigran.

Orang Indo di Belanda tidak membangun pilar (zuil) tersendiri, kecuali organisasi-organisasi yang menyelenggarakan pertemuan yang bersifat menguatkan rasa kekerabatan melalui kegiatan ilmiah, seni, dan kedermawanan seperti membangun dan menjalankan rumahrumah perawatan orangtua. Salah satu yayasan, HALIN (Hulp aan Landgenoten in Indonesia), menggalang dan mendistribusi dana untuk membantu para Indo yang kurang sejahtera di Indonesia.

\section{Simpulan}

Dari kajian ini dapat disimpulkan tiga hal pokok. Pertama, perwujudan keindoan (sebagai identitas dengan segala atribut budayanya) tergantung kepada ruang yang diberikan oleh negara, dan hal ini tergantung

\footnotetext{
${ }^{9}$ Para narasumber saya kebetulan tidak sependapat, bahkan mencemooh tokoh ini, menyebutnya sebagai "orang yang lupa pada jati dirinya" (identiteits-vervreemding).
} 
kepada negara mana yang berkuasa. Pada konteks kekuasaan Belanda di Hindia Belanda, identitas dan atribut keindoan penting dan menguntungkan, dan karenanya diaktifkan. Orang Indo menonjolkan kebelandaannya pada masa kolonialisme Hindia Belanda dan setelah mereka pindah ke Belanda, terutama pada dua generasi pertama. Pada konteks negara yang dikuasai oleh bukanBelanda, tidak ada ruang bagi perwujudan identitas keindoan. Di masa pendudukan Jepang yang mengunggulkan keasiaan dan masa dekolonisasi yang mengunggulkan keindonesiaan, atribut Belanda pada identitas Indo ditekan, disembunyikan atau diganti.

Kedua, orang Indo di Belanda tidaklah homogen. Keragaman orang Indo di Belanda dapat dilihat dari hubungan di antara generasi dengan sejarah kolonialisme Belanda. Pentingnya melihat generasi juga terkait dengan kebijakan kewargaan pemerintah Belanda terhadap latar belakang migrasi. Dua generasi pertama Indo di Belanda masih digolongkan sebagai migran keturunan asing (allochtonen), yang harus berasimilasi kepada masyarakat dan kebudayaan Belanda.

Generasi pertama Indo, dengan modal budaya Belanda dari masa kolonial, umumnya berusaha keras membelandakan diri, mengubah posisi dari imigran menjadi warga negara Belanda, sehingga membatasi penggunaan atribut 'Hindia' atau 'pribumi' dari keindoan hanya di lingkungan sosial terdekat. Hal ini, juga fakta bahwa penggantian kerugian bagi orang Indo baru tuntas pada tahun 2001, menyiratkan sisa-sisa kebijakan kolonial tentang pembedaan kewargaan, meskipun semuanya terjadi di negeri Belanda pascakolonial. Temuan penting lainnya adalah bahwa pendakuan akan keindoan (seperti upaya Tjalie Robinson), serta pengakuan dan perolehan hak-hak mereka sebagai warga negara Belanda, juga merupakan hasil dari politik kewargaan orang Indo sendiri, bukan pemberian atau pengakuan otomatis dari pemerintah Belanda.
Sesungguhnya pada generasi kedua, beban asimilasi ke masyarakat dan kebudayaan Belanda lebih ringan, berkat pendidikan dan perkawinan dengan pasangan bukan-Indo. Di sisi lain, berkurangnya beban berasimilasi justru menjadi ruang bagi generasi kedua untuk aktif menelusuri masa lalu. Di antara temuan mereka adalah isu kekurangpedulian pemerintah Belanda kepada orang Indo.

Generasi ketiga yang sudah tidak memiliki kaitan dengan masa lalu kolonial, secara resmi tidak dihitung sebagai keturunan asing lagi, tetapi sebagai warga Belanda (autochtonen). Bagi mereka, keindoan bukan sekadar identitas yang diwarisi dan statis, melainkan identitas yang dipilih dan dikembangkan sendiri pada aras individu sebagai pembeda yang menyenangkan dari liyan. Keagenan pada generasi ini menjadi lebih aktif. Temuan ini sejajar dengan studi Oostindie tentang masyarakat Belanda pascakolonial (2011) dan studi lain tentang kebudayaan dan generasi Indo (De Vries, 2012; Iburg, 2013), bahwa generasi termuda tidak terlalu mempedulikan keindoan mereka. Mereka memandang diri sebagai warga Belanda, sekaligus warga dunia. Generasi ini tumbuh selagi masyarakat Belanda semakin multikultural. Pengalaman lintas-generasi Indo yang terserap, membuat mereka peka terhadap pengaturan kewargaan di Belanda, dan memiliki empati terhadap imigran dari negeri lain yang, seperti leluhur mereka, harus beradaptasi dengan kehidupan masyarakat Belanda.

\section{Daftar Pustaka}

Baay, R. (2008). De Njai: Het concubinaat in Nederlands-Indië.

Boon, S., dan Geleuken, E. (1993). Ik wilde eigenlijk niet gaan: De repatriëring van Indische Nederlanders 1946-1964. Den Haag: Stichting Tong Tong.

Bosma, U., dan Remco, R. (2008). Being Dutch in the Indies: A History of Creolization and Empire, 1500-1920. Singapore \& Athens: NUS \& Ohio University Press.

Coté, J., dan Westerbeek, L. (eds.). (2014). Recalling the Indies: Colonial culture and postcolonial identities.

De Vries, M. (2009). Indisch is een gevoel: De tweede en derde generatie Indische 
Nederlanders. Amsterdam: Amsterdam University Press.

Frederick, W. H. (2010). The killing of Dutch and Eurasians in Indonesia's national revolution (1945-1949): A 'brief genocide' reconsidered. Journal of Genocide Research, 14(3-4)), 359-380.

Groenewald, R.E. (2009). Indo ... Indonesier of Hollander. T.p.

Iburg, N. (2013). Van Pasar Malam tot I Love Indo: Identiteitsconstructie- en manifestatie door drie generaties Indische Nederlanders. Cetakan Ketiga. Arnhem: Uitgeverij Elessy.

Jonathans, Yano. 2011. Potret Kehidupan Sosial dan Budaya Masyarakat Depok Tempo Doeloe. Jakarta: Penerbit Libri.

Knörr, J. (2008). Towards Conceptualizing Creolization and Creoleness. Halle/Saale: Max Planck Institute of Social Anthropology.

Memmi, A. (1965). The Colonizer and the Colonized. Boston: Beacon Press.

Nieuwenhuys, R. (1978). Oost-Indische spiegel. Em. Querido's uitg.

Oldenburg, Ray (1989). The Great Good Place: Cafes, Coffee Shops, Community Centers, Beauty Parlors, General Stores, Bars, Hangouts, and How They Get You Through the Day. New York: Paragon House.

Oostindie, G. (2011). Postcolonial Netherlands: Sixty five years offorgetting, commemorating, silencing. Amsterdam: Amsterdam University Press.

Oostindie, G. (pny. ). (2008). Dutch Colonialism, Migration, and Heritage. Leiden: KITLV Press.

Patterson, O. (1975). Context and Choice in Ethnic Allegiance: A Theoretical Framework and Caribbean Case Study. Dalam Glazer, Nathan, Moynihan, dan P. Daniel (Eds.), Ethnicity - Theory and Experience. Cambridge, Mass. and London: Harvard University Press.

Pattipilohy, C. (2009). Jeugdherinneringen van een 'Inlandse Indische.' Indische Letteren. Jaargang 24, 22-34.

Pollmann, T., dan Harms, I. (1987). In Nederland door omstandigheden. Baarn/Den Haag: Ambo/Novib.

Seriese, E. (2005). In flarden en bronstukgewijs: Opsporen, benoemen en presenteren dan immaterieel cultureel erfgoed volgens Kumpulan. Almere: Indisch Wetenschappelijk Instituut.

Soekiman, D. (2000). Kebudayaan Indis dan gaya hidup masyarakat pendukungnya di Jawa, abad XVIII-medio abad XX. Yogyakarta: Yayasan Bentang Budaya.

Staal, D. (2012). Zoektocht naar een Indisch verleden. Univesity of Leiden.

Steijlen, F. (2014). Pasar Malam Indo-Eropa: Identitas dan Pertunjukan Kebudayaan di Belanda. Dalam: B. Hatley, G.B. Subanar dan Y.D. Ardhiani (ed.), Seni Pertunjukan Indonesia Pasca Orde Baru. Yogyakarta: Penerbit Universitas Sanata Dharma. Hlm. 245-266

Stewart, C. (2007). Creolization: History, Ethnography, Theory. London \& New York: Routledge.

Tjen-A-Kwoei, E. (2013). Drie Werelden, Eén Huwelijk. Rotterdam: Pluspunt.

Van Delden, M.C. (1989). Bersiap in Bandoeng: Een onderzoek naar geweld in de periode van 17 augustus 1945 tot 24 maart 1946. Kockengen: Van Delden.

Voskuil, E.A., R.G.P.A. (1996). Bandoeng, Beeld van een Stad. Purmerend, Nederland: Asia Maior. 